\title{
A review of fractals in karst
}

\author{
Eulogio Pardo-Igúzquiza ${ }^{*}$, Peter A. Dowd ${ }^{2}$, Juan J. Durán ${ }^{1}$, and Pedro Robledo-Ardila ${ }^{3}$ \\ ${ }^{1}$ Instituto Geológico y Minero de España (IGME), Ríos Rosas 23, 28001 Madrid, Spain \\ ${ }^{2}$ Computer and Mathematical Sciences, The University of Adelaide, Adelaide SA 5005, Australia \\ ${ }^{3}$ Unidad del IGME en las Islas Baleares. C/Felicià Fuster 7, 07006. Palma de Mallorca, Spain
}

\begin{abstract}
Many features of a karst massif can either be modelled using fractal geometry or have a fractal distribution. For the exokarst, typical examples include the geometry of the landscape and the spatial location and size-distribution of karst depressions. Typical examples for the endokarst are the geometry of the three-dimensional network of karst conduits and the lengthdistribution of caves. In addition, the hydrogeological parameters of the karst massif, such as hydraulic conductivity, and karst spring hydrographs may also exhibit fractal behaviour. In this work we review the karst features that exhibit fractal behaviour, we review the literature in which they are described, and we propose hypotheses and conjectures about the origin of such behaviour. From the review and analysis, we conclude that fractal behaviour is exhibited at all scales in karst systems.
\end{abstract}

Keywords: $\quad$ scale-invariance, self-similarity, landscape, sinkholes, caves, conduit networks

Received 27 June 2018; Revised 11 October 2018; Accepted 11 October 2018

Citation: $\quad$ Pardo-Igúzquiza E., Dowd P.A., Durán J.J. and Robledo-Ardila P., 2019. A review of fractals in karst. International Journal of Speleology, 48 (1), 11-20. Tampa, FL (USA) ISSN 0392-6672 https://doi.org/10.5038/1827-806X.48.1.2218

\section{INTRODUCTION}

Scale-invariance and self-similarity (Mandelbrot, 1967; Stoyan \& Stoyan, 1994; Ben-Avraham \& Havlin, 2000) are important concepts in geology (Korvin, 1992; Turcotte, 1997) in general, and in geomorphology (Dodds \& Rothman, 2000) in particular. A third concept of universality (Sapoval, 2001) is becoming more evident and relevant as, increasingly, spatial structures of very different physical origin are being shown to exhibit similar spatial patterns, which is reflected in the exponents that characterize their scaling laws. The geometry of river networks (Tarboton et al., 1988; Nikora \& Sapozhnikov, 1993; Rodriguez-Iturbe \& Rinaldo, 2001) and the statistical structure of topography (Xu et al., 1993; Klinkenberg \& Goodchild, 1992) are typical examples of fractals in geomorphology (Dodds \& Rothman, 2000). These concepts are increasingly evident in so many areas of Earth Sciences that the hypothesis is shifting towards whether nature itself is fractal (Mandelbrot, 1983; Avnir et al., 1998).

Loosely speaking, a geometrical object or a set is said to be fractal if it exhibits at least one self-similar property in an exact way (deterministic fractals) or through a probabilistic distribution (random or statistical fractals), (Hutchinson, 1981; Falconer, 1990; Schroeder, 1991).
For our presentation and subsequent discussion, we follow the distinction of geometric fractals and probabilistic fractals as described in Crovelli \& Barton (1995) and in Ghanbarian \& Hunt (2017): fractal geometries of random sets and properties (random variables) of random sets for which the probability density function follows a power law (fractal-like behaviour). The former has a fractal dimension that describes its irregularity or how a random set in a topological space of integer dimension $i$ fills the fractal space of non-integer dimension greater than $i$. The latter does not have a fractal dimension but has an exponent that characterizes the power law; the characteristic analysed (for example, size) can be considered a random variable for which the probability density function is a power law and there is no need to relate it to an irregular geometry. In any case, the essential assumption of the fractal model is selfsimilarity which makes it possible to describe fractals by parameters that are either dimensions (fractal geometry of a set) or exponents (fractal property of a set).

Geometrical fractals are geometric shapes or patterns that have a fractional dimension (i.e., the fractal dimension of the geometry of a given set of interest). The fractal dimension can be estimated by different methods. For example, the fractal dimension of a one-dimensional geometry (e.g., a contour), that 
characterizes its irregularity, can be determined by calculating its length using measures of different size. If the line is fractal, the relationship between the length of the line and the length of the measure would be expected to follow a power law of the form (Stoyan \& Stoyan, 1994):

$$
l(r)=c r^{1-D}
$$

where $c$ is a constant. A perfect straight line, i.e. without irregularities, will still follow the power law in equation (1), but with $D=0$ that is, its dimension is integer not fractal.

Taking logarithms of both sides of the equation (1) gives:

$$
\ln l(\mathrm{r})=\ln c-(1-\mathrm{D}) \ln r
$$

which is the equation of a straight line with a slope equal to one minus the fractal dimension. Similar power laws are used in other methods to estimate the fractal dimension of sets in the plane and in three dimensions.

Probabilistic fractals (i.e., random variables with fractal behaviour) have a probability density function that follows a power law distribution, which requires that the number of objects, $N$, with a size greater than $r$, follows a power law distribution:

$$
N(R>r)=A r^{-K}
$$

where $R$ is a measurable property, $A$ is a constant and $K$ is the exponent characterising the power law.

Thus, power law behaviour can be assessed by studying the probability distribution fitted to a given set of data. This distribution could, for example, take the form of Zipf's law (Laverty, 1987; Schroeder, 1991) or the Korcak-law (Mandelbrot, 1975; Imre and Novotny, 2016). The power-law distribution is a scale-free distribution and represents the spatial distribution of phenomena that do not have a characteristic size but one that varies across several orders of magnitude. Taking logarithms of both sides of equation (3) gives:

$$
\ln N=\ln A-K \ln r
$$

which is the equation of a straight line with a slope equal to the Korcak exponent. Thus, probabilistic fractals are characterized by the exponent of a power law. In some cases, this exponent is related to a fractal dimension (Jang \& Jang, 2012).

It should be noted that size, shape, abundance, spatial location and distribution of karst geoforms can have a fractal behaviour. In addition, the same geoform can be assessed from several points of view. For example, we can calculate the fractal dimension of the irregularities of the contour of a single sinkhole (or doline). For a family of sinkholes in a given karst terrain, which have been mapped by appropriate means, there are various aspects that could be assessed for fractal behaviour; for example, their sizedistribution and the spatial location of their centroids. For geometrical fractals, the fractal dimension (the exponent in the power law in equation 1) describes, in simple terms, how the fractal object fills the available Euclidean space. The contour (one-dimensional object) of a sinkhole on a plane (two-dimensional Euclidean space) will be a number between 1 and 2 . The larger the number, the more irregular is the contour. For probabilistic fractals, the interpretation of the fractal dimension is related to the frequency of the size of the objects. The frequency of an occurrence of a given size is inversely proportional to some power of its size. In karst terrains, fractality (i.e. karst features that can be modelled using fractal geometry or karst characteristics that have a fractal distribution) can be found in the exokarst, the endokarst and the karst hydrogeology, which we review in separate sections.

\section{FRACTALS IN THE EXOKARST}

Sinkholes (or dolines) are considered the most typical landform in karst landscapes (Ford \& Williams 2007). As areas of preferential recharge, they have important implications for karst hydrogeology. They trap sediments that can provide information about past climate conditions, they may indicate geological tectonic activity and they can host important ecosystems.

Reams (1992) found that sinkhole perimeters of large sinkholes appear to be fractals with fractal dimensions ranging from 1.20 to 1.56 ; i.e., the contours of sinkholes have irregularities that can be quantitatively assessed by their fractal dimension. The same author also concludes that large sinkhole size-number distributions are fractal. Nevertheless, it should be noted that White \& White (1987) were the first to test sinkhole populations for their fractal character and their results were negative.

The results of a fractal analysis of sinkholes depend on how the experimental data are obtained. Thus, if data are obtained from maps which are not on a sufficiently small scale, only large sinkholes can be mapped, and the level of detail in the contours will not be sufficient for the analysis, as they will be much smoother than reality. This may explain why the sizedistribution of dolines has long been assumed to be log-normal (Telbisz et al., 2009).

The situation has changed with modern digital elevation models (DEM) of topography that allow, subject to the DEM resolution, the detection and delineation of karst depressions in an automatic, exhaustive and efficient manner (Pardo-Igúzquiza et al., 2013; Pardo-Igúzquiza et al., 2014a). Fig. 1 shows the high-quality resolution of mapped sinkholes in the Sierra de las Nieves karst massif in Southern Spain using a DEM with a resolution of $5 \mathrm{~m}$, i.e., each cell of the DEM represents the altitude of a pixel of $5 \mathrm{~m}$ by $5 \mathrm{~m}$ in terrain units. The authors of this work have verified the procedure in the field and even one-cell karst depressions proved to be real dolines in the field. It should be noted that the success of this method also depends on high-quality altimetric precision of the DEM. Thus, the mapped depressions are reliable, and the contours of the sinkholes in Figure 1 do not have the irregularities that would have been introduced if the DEM was noisy and of poor quality. The DEM was obtained as a free download from the web-site of the Instituto Geográfico Nacional of Spain. The DEM for the whole country (an area of 

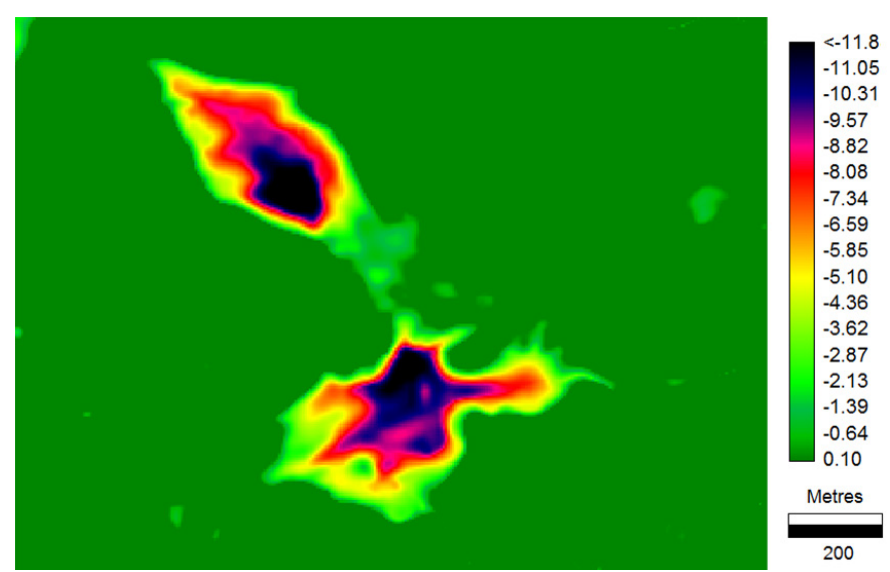

Fig. 1. High resolution karst depressions (dolines and uvalas) mapped by an automatic procedure (Pardo-Igúzquiza et al., 2013) and using a digital elevation model with a resolution of $5 \mathrm{~m}$ (size length of the square pixel or cell). The map legend is the depth of each karst depression (in metres) from its rim. The high quality of the mapped contours of the depressions and of the mapped depth is evident.

half a million of square kilometres) has a resolution of $5 \mathrm{~m}$ and for many parts of the country the resolution increases to $1 \mathrm{~m}$. All mapped karst depressions are shown in Figure 2. The power-law size-distribution of the population of sinkholes is shown in Figure 3.

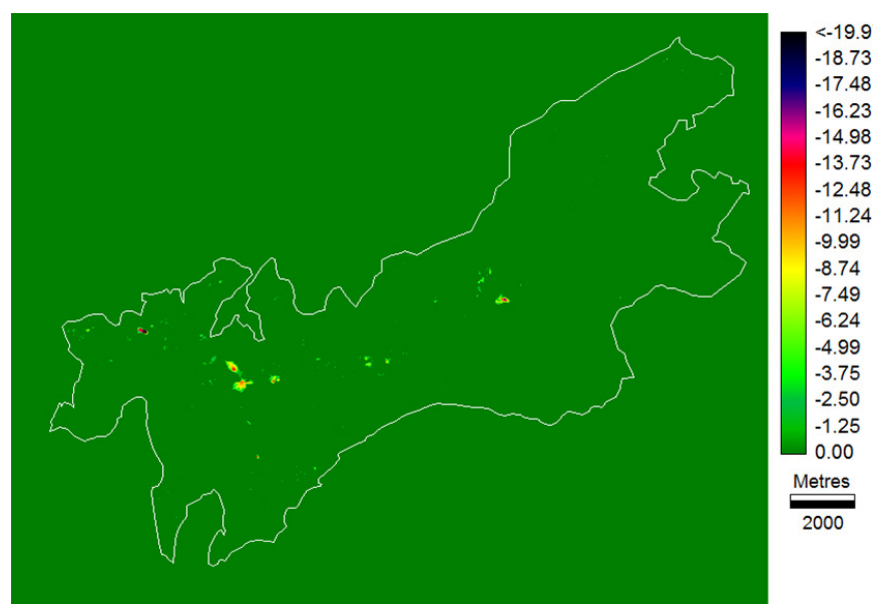

Fig. 2. Karst depressions (dolines and uvalas) in the Sierra de las Nieves karst massif in Southern Spain. The statistics of these sinkholes are given in Pardo-lgúzquiza et al. (2016b).

The same procedure can be used to map karst hills as described in Pardo-Igúzquiza et al. (2016b). The fractal dimension of these doline fields can be used as a geomorphometric parameter to compare different karst massifs.

Other aspects of sinkholes can be assessed when each sinkhole is replaced by its centroid, giving a spatial distribution of points in the plane. Figure 4A shows the point field obtained with the 3,100 sinkholes of the karst massif of Sierra Gorda (López-Chicano, 1995) in Southern Spain and Figure 4B shows the 2,457 sinkholes of the karst massif of Cotiella (BelmonteRibas, 2004) in Northern Spain. The fractal dimension of a point field can be assessed by the pair correlation function (Bour et al., 2002):

$$
C(r)=\frac{2 N_{p}(r)}{[N(N-1)]}
$$

where $C(r)$ is the pair correlation function; $N_{p}(r)$ is the number of pairs separated by a distance less than $r$ and $N$ is the total number of points.

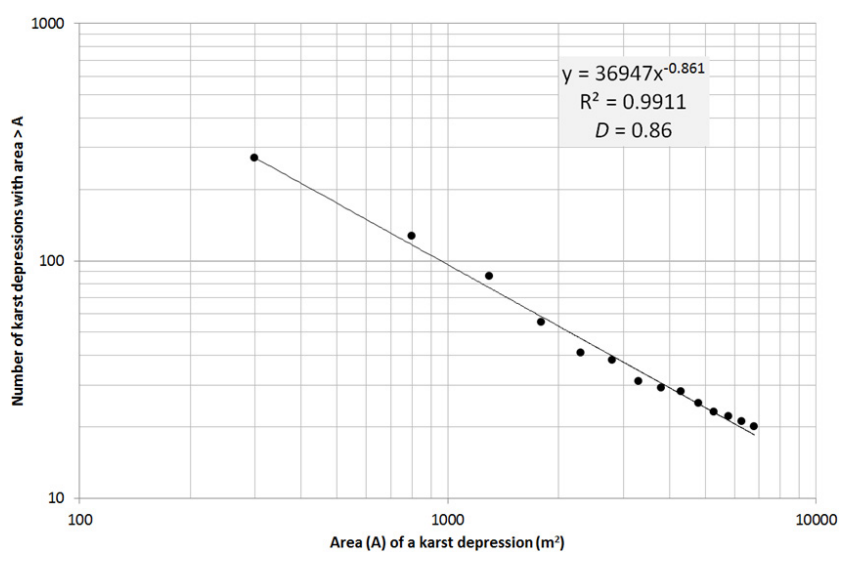

Fig. 3. Graph showing a power law fitted to the number of sinkholes (shown in Fig. 2) with an area larger than a value given by the $X$ axis. The straight line in a log-log plot indicates fractal behaviour. The fractal exponent of the power law is equal to 0.86 .

If the point field has a fractal behaviour, the correlation function will scale with distance following a power-law:

$$
C(r) \propto r^{D_{M}}
$$

where $D_{M}$ is the so-called mass fractal dimension.

A third point field is shown in Fig. $4 \mathrm{C}$, in which each point represents a galaxy. Fig. $4 \mathrm{C}$ is a full cylinder section of the 2MASS Redshift Survey database (Huchra et al., 2012). The thickness of the cylinder is $1,000 \mathrm{~km} \mathrm{~s}^{-1}$, and its radius is $15,000 \mathrm{~km} \mathrm{~s}^{-1}$. The mass fractal dimension has been calculated for the three point-fields in Figure 4 and the results are shown in Figure 5. The mass fractal dimensions for the Sierra Gorda karst massif, Cotiella karst massif and celestial galaxies map are, respectively, 1.67, 1.46, and 1.25. The Cotiella and galaxies graphs in Figure 5 are similar for short distances. These figures confirm the intuitive similarity of the spatial patterns in Figure 4 and they reflect the universality of the fractal law: very different physical processes give rise to similar spatial patterns. Pardo-Igúzquiza et al. (2016c) and Yizhaq et al. (2017) have recently demonstrated the fractal character of sinkholes.

Other important aspects of the exokarst are the karst landscape (or karst topography) and karren (Ford \& Willians, 2007). Karren has also been shown to be a scale-free karst surface dissolution feature. Maire et al. (2004) found that different types of karren have a fractal character, although they do not provide the fractal exponents of the karren scaling.

We now review the fractal character of karst landscapes. Fractal analysis of surface roughness has been widely used for both the natural landscape (Borrough, 1981; Klinkenberg \& Goodchild, 1992; Xu et al., 1993, Liucci \& Melelli, 2017) and artificial surfaces (Persson, 2014). This type of analysis has improved with the availability of digital elevation models that allow global and local fractal dimensions of landscape to be calculated.

The global fractal dimension quantifies in a single number the complexity and irregularities of the landscape, while the local fractal dimension provides a spatial map of the landscape fractal dimension that quantifies the variations in landscape roughness across the study area. The resulting fractal dimensions 
have been used as geomorphometric parameters and as textural indices (Taud \& Parrot, 2005). There are no widely available studies of the fractal analysis of karst landscapes and the most recent account is provided
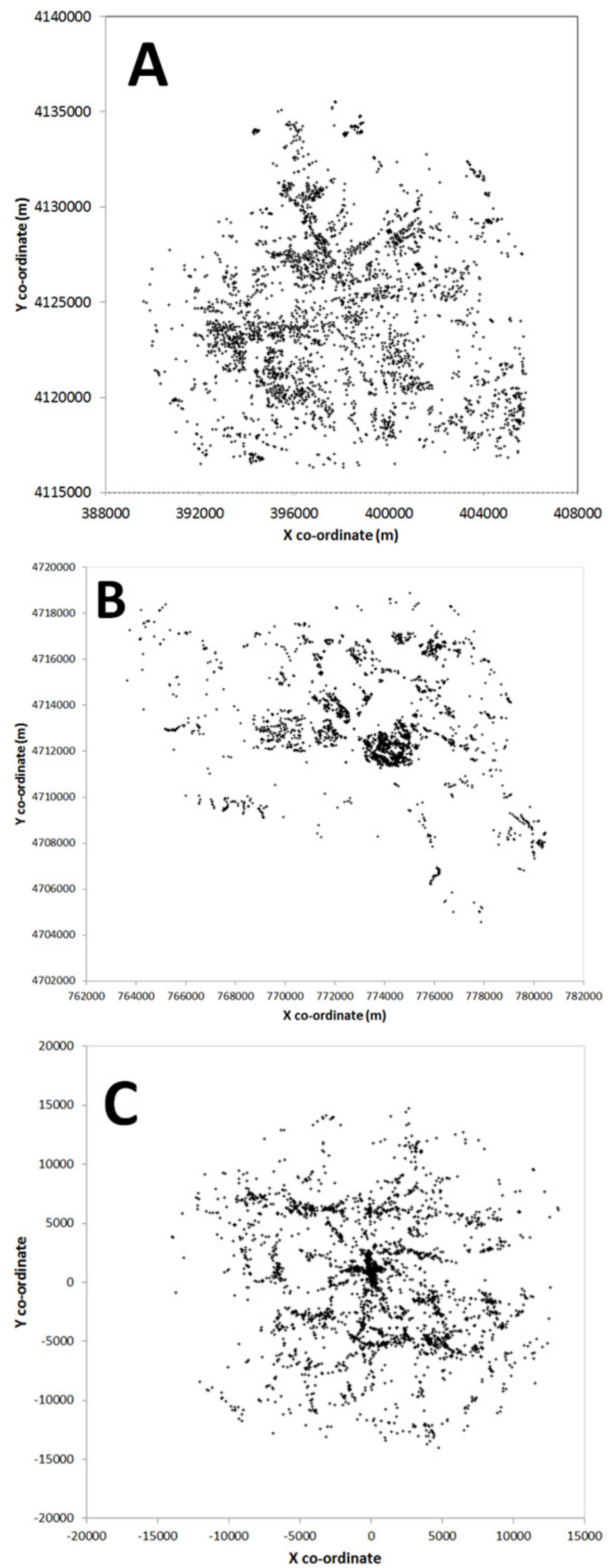

Fig. 4. A) Sierra Gorda karst massif point field in which each point is the location of a doline; B) Cotiella karst massif point field in which each point is the location of a doline; C) Top-down view of a cylindrical portion of the universe where each point represents a Galaxy. by Pardo-Igúzquiza \& Dowd (2018). In the latter reference the variogram is used to estimate the local fractal dimension of a karst massif and the authors conclude that the complexity of the karst landscape, as revealed by local fractal analysis, is related to the abundance of karst depressions and karst hills on a range of scales accessible from the available digital elevation model.

This complexity can be assessed for different zones of the study area by calculating the histogram of the local fractal dimension of specified areas. Remarkably, they also found that most local fractal dimensions in karst terrains are less than 2.3, as was theoretically proposed by Persson (2014) for natural and engineered surfaces.

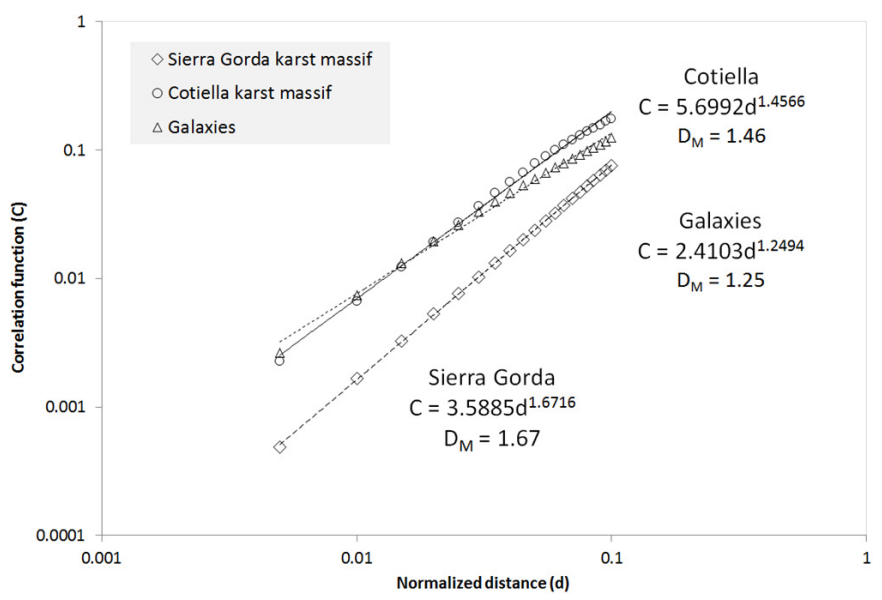

Fig. 5. Pair correlation functions for the point fields in Fig. 4. The distance has been normalized by the maximum distance between points in each set. The mass fractal dimension DM is 1.67, 1.46 and 1.25 for the Sierra Gorda karst, Cotiella karst and galaxies, respectively.

\section{FRACTALS IN THE ENDOKARST}

Several decades ago Curl $(1960,1966)$ showed that the length-distribution of caves is fractal and the number of caves, $N$, of length greater than $l$, is given by:

$$
N(l)=N\left(l_{0}\right)\left(\frac{l}{l_{0}}\right)^{-D}
$$

where $N\left(l_{0}\right)$ is the number of caves with a length greater than a reference length $l_{0}$. Clearly, equation (7) is another form of equation (3) but it is included here to recognize the pioneering work of Curl not just in fractals in karst science but also as one of the first applications of fractals in general. Curl (1986) obtained, for most of the examined cases, a value of $D$ around 1.4 (with values ranging from 1.2 to 1.6). Curl (1986) also showed that the conditional distribution of sizes of modular elements (caves limited by passages smaller than a given size) also has a fractal distribution; he obtained a value of 2.8 for the Little Bruce Creek cave in the United States. This value of 2.8 is close to the fractal dimension of a Menger sponge, which has a fractal dimension of $\log (20) / \log (3)=2.727$ (Fig. 6A). Figure 6B shows a limestone slate that can be represented as a stochastic Menger sponge. The voids in Figure 6B are not caves (Curl, 1964, 1986) but porosity that can be regarded as micro-caves. In principle, these micro-caves could 
be accessed and mapped by micro-electronic or other means. Thus, the fractal analysis of karst conduits is more general than the fractal analysis of proper caves (caves accessible by humans).

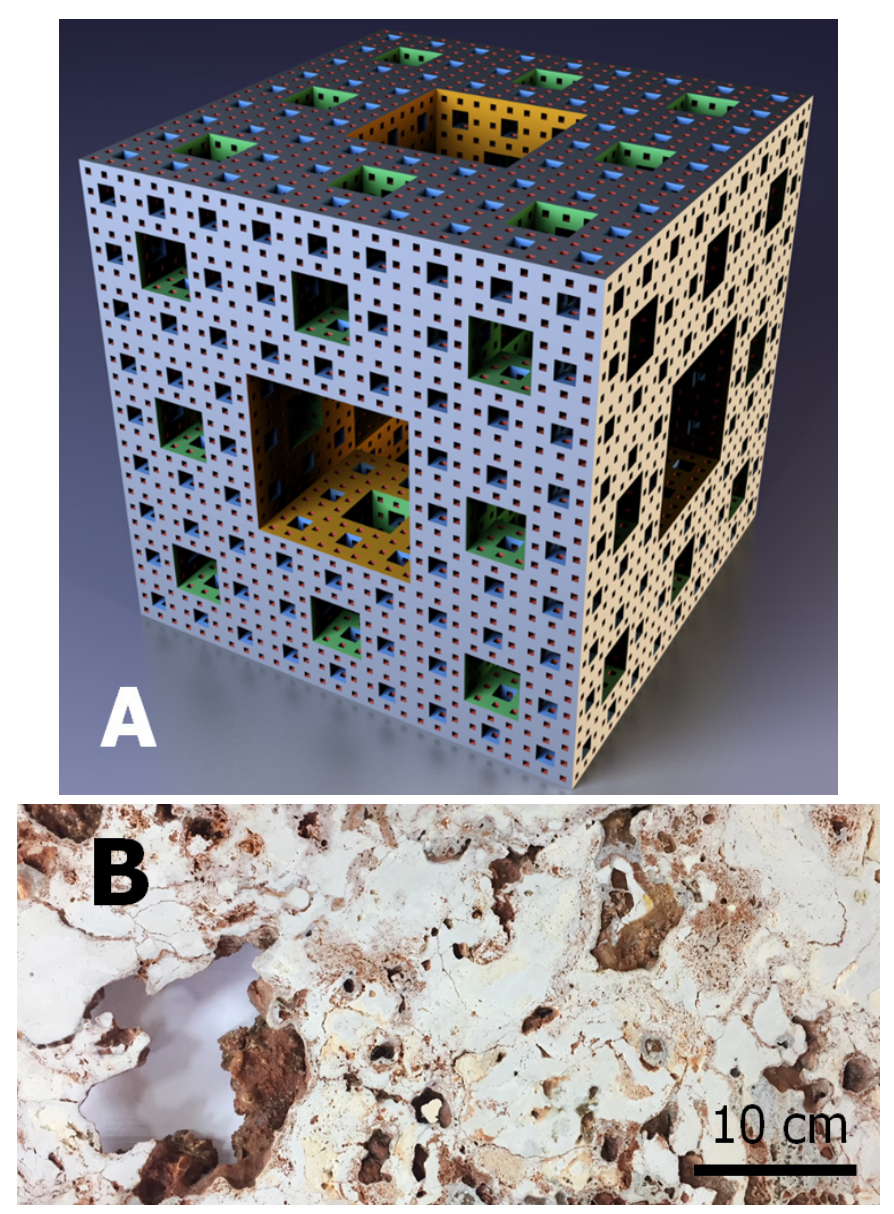

Fig. 6. A) Menger sponge, a deterministic fractal after four iterations in its construction. Figure from Wikipedia created and distributed by Niabot under the GNU Free Documentation Licence; B) Fragment of an Upper Miocene reef limestone slate that can be represented as a stochastic Menger sponge.

Karst conduits are formed from the dissolution of fractures and by bedding planes and other lithological or structural discontinuities in carbonate rocks. The exhaustive network of karst conduits is not observed and mapped by speleological exploration, which is limited to the mapping of accessible caves or accessible parts of caves. Additionally, speleological mapping is biased because not all existing passages have been found, not all the found passages have been explored and not all existing passages are accessible. Nevertheless, based on speleological data, Pardo-Igúzquiza et al. (2014a) used fractal extrapolation to estimate the conduit porosity of the Sierra de las Nieves Karst aquifer in Southern Spain. In addition, fractal dimension was proposed as a geo-morphometric descriptor of three-dimensional networks of karst conduits (Pardo-Igúzquiza et al., 2011) and the fractal character of these networks was used in Pardo-Igúzquiza et al. (2012) to generate realistic synthetic networks of karst conduits using a diffusion limited aggregation method. The fractal dimension of these networks has a typical value of 1.67 (Jeannin et al., 2007). However, in practice, smaller values are usually estimated. For example, experimental values of 1.65 for a karst network in
France (Pardo-Igúzquiza et al., 2011), 1.50 for the Yukatan karst networks (Hendrick \& Renard 2016a), 1.50 for a karst network in China (Pardo-Igúzquiza et al., 2012) and 1.23 and 1.63 for two different karst networks in Spain (Pardo-Igúzquiza et al., 2016, a, b). These smaller values may be due to the fact that some parts of the system are still unexplored, which suggests the possible use of the fractal dimension to estimate the percentage of a karst network that has not yet been discovered. The value of 1.67 (Jeannin et al., 2007) is the fractal dimension of a self-avoiding random walk (Havlin \& Ben-Avraham, 1982). Other studies of the fractal dimension of cave systems can be found in Kusumayudha et al. (2000) and Verbovšek (2007) and a study of the fractal dimension of gypsum cave networks can be found in Andreychouk et al. (2013).

An example of the universality of fractals, with respect to these networks of caves, is provided in Figure 7 which shows the three-dimensional representation of the Shuanghe network (Bottazi, 2004; Pardo-Igúzquiza et al., 2012) and the projection of the network onto the horizontal plane. Figure 8A shows the projection of the Sakany network (Cassou y Bigot, 2007; PardoIgúzquiza et al., 2011) onto the horizontal plane, which can be compared with the map of the underground rail system of the city of Madrid (Fig. 8B). This is another example of fractal universality where very different physical processes (in $8 \mathrm{~A}$ a natural process and in $8 \mathrm{~B}$ a man-made structure) have similar spatial patterns, as can be qualitatively assessed by visual comparison of both figures. The network of karst conduits in Figure $8 \mathrm{~A}$ is optimal for draining the water of a karst massif while the underground network in Figure $8 \mathrm{~B}$ is optimal for the transportation and distribution of people in a large city. Nevertheless, it should be noted that the network of karst conduits is the result of a complex process that has taken place over a long (geological) time. During this time some parts of the system that were optimal for given climatic conditions may have become inactive but remain part of the network structure. Thus, the network of karst conduits is optimal in a global historical sense.

Adequately capturing the complexity of karst networks by mapping is the most challenging aspect of karst modelling especially for modelling and predicting flow and transport in karst media (Ford \& Ewers, 1978; Kaufmann \& Braun, 2000; Bakalowicz, 2005). Using a lumped model of a karst system and assuming a fractal structure for the karst media, Maramathas \& Boudouvis (2006) show that the power law is the optimal relationship between certain parameters of a MODKARST spring model and gives the best agreement between field measurements and model-calculated values of chloride concentration.

\section{FRACTALS IN KARST HYDROGEOLOGY}

In a karst massif there are three types of coexisting porosity: rock matrix porosity, fracture porosity and conduit porosity. The three types of porosity have fractal behaviours. Conduit porosity is the ratio of the volume of conduit voids to the total volume and can 


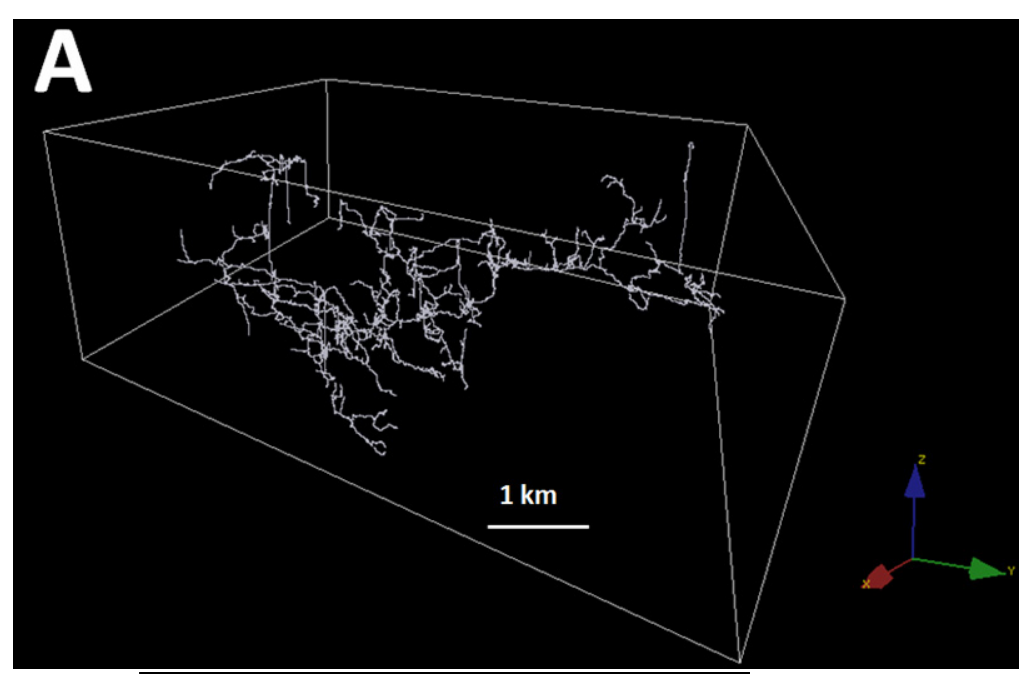

this three-dimensional network implies a hierarchization of flow (Lauber et al., 2014), in the same way as there is hierarchization of surface flow in a river network (RodriguezIturbe \& Rinaldo, 2001), and this hierarchical network of karst conduits is fractal. This implies that there is no typical scale of permeability in carbonate aquifers; the scale increases with the observation scale (Ford \& Williams, 2007, Fig. 5.2). This self-organization complexity is general in geomorphology as pointed out by Turcotte (2007).

Hergarten \& Birk (2007) found that, during the recession of karst spring hydrographs, there is a power-law decrease of discharge over short times after a rainfall event. The discharge at short times after rainfall events involves fast

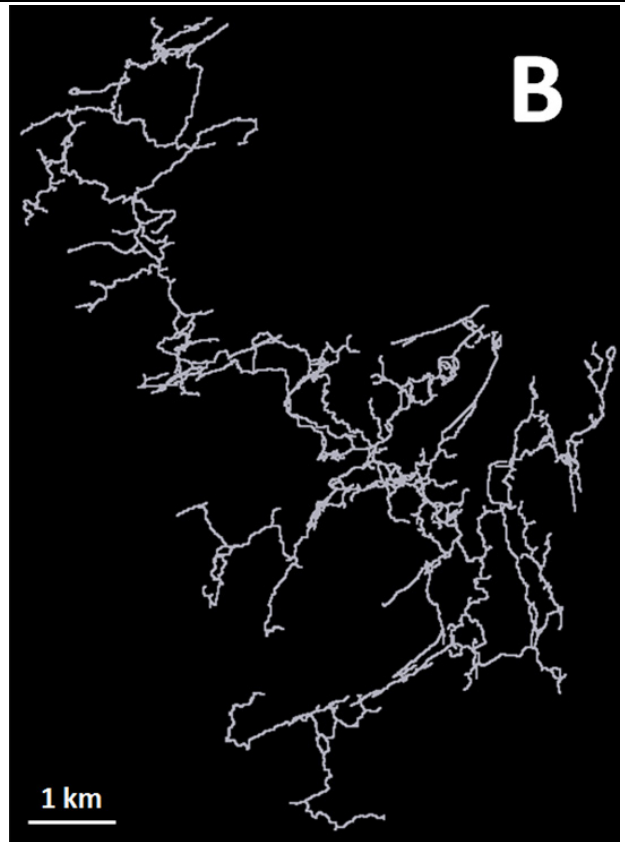

Fig. 7. A) the $130 \mathrm{~km}$ of karst conduits of the subtropical Shuanghe network in China; A) 3D view of the network in which the Z-axis scale has been magnified by a factor of 5 ; B) projection of the network onto the $\mathrm{X}-\mathrm{Y}$ plane.

be calculated by fractal extrapolation using the fractal character of karst conduits (Pardo-Igúzquiza et al., 2014a). Fracture porosity is the ratio of the volume of fracture voids to the total volume and depends on the extent and apertures of fractures. The fractal character of fractures has been amply demonstrated in the literature (Berkowitz, 2002; Mace et al., 2005). Finally, matrix rock porosity can be observed in hand samples, such as the one shown in Figure 4B, and in thin-section photographs (Fig. 9). The internal surfaces of the pores are very rough due to dissolution and mineralization (Fig. 9). The fractal character of (general) porous media has been widely studied and reported (Katz \& Thompson, 1985; Lenormand, 1997; Yu \& Liu, 2004).

With respect to hydraulic conductivity, Worthington $\&$ Ford (2009) recognized the self-organized character of permeability in carbonate aquifers. This is due to the dissolution and enlargement of fractures, bedding planes and other rock discontinuities that occur along the entire length of pathways through carbonate aquifers, which results in a network of channels at all scales. The self-organization of flow through the network of karst conduits, which has a fractal geometry (Shevenell, 1996; Bacdk \& Krothe, 2001).

Hendrick \& Renard (2016a) use transport properties in the fractal characterization of karst networks and show that, for two large networks, conductivity scales
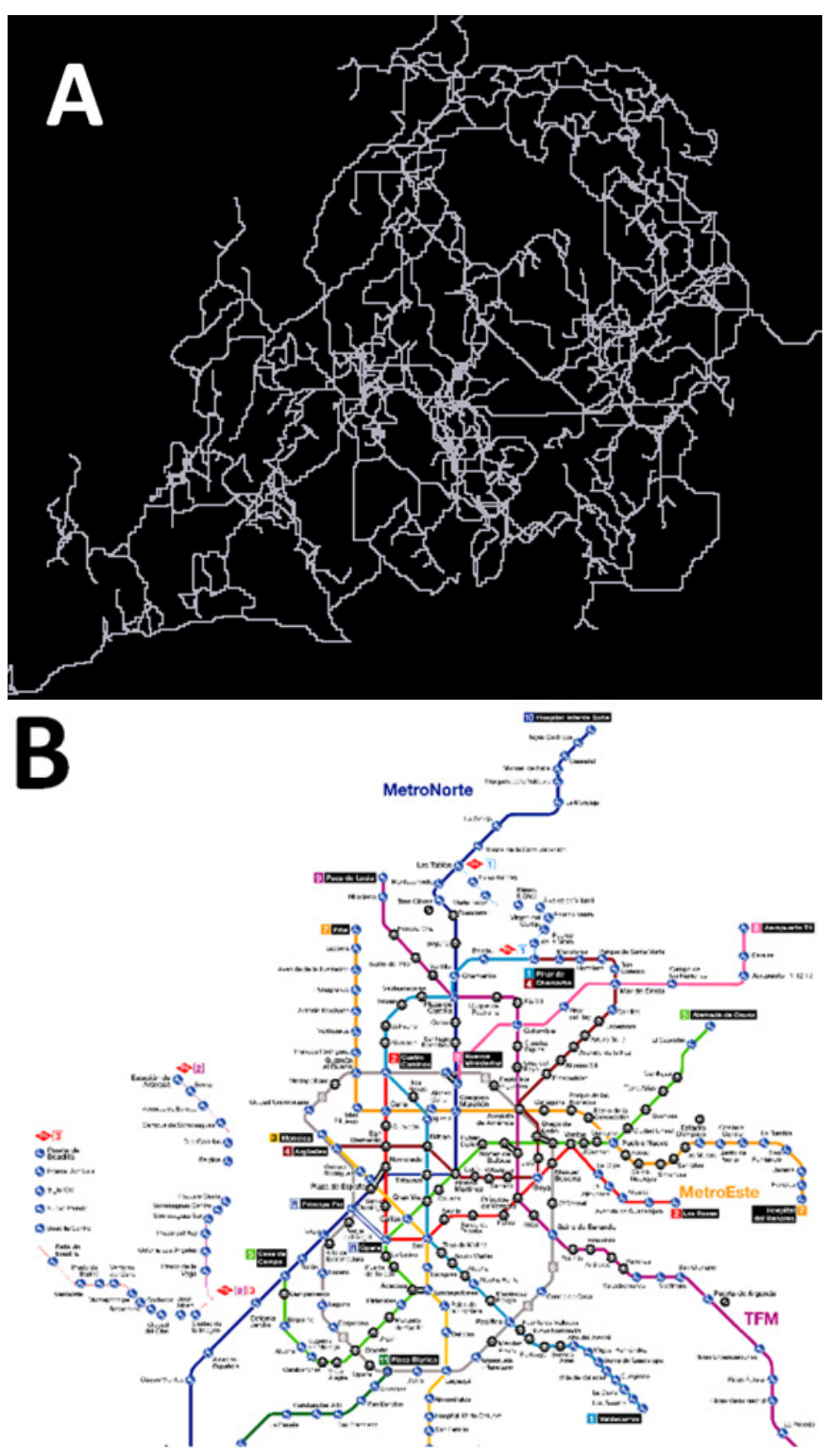

Fig. 8. A) Projection of the Sakany network (France) onto the $X-Y$ plane; B) Underground rail map of the city of Madrid (Consorcio de Transportes Madrid, Comunidad de Madrid, Spain). 


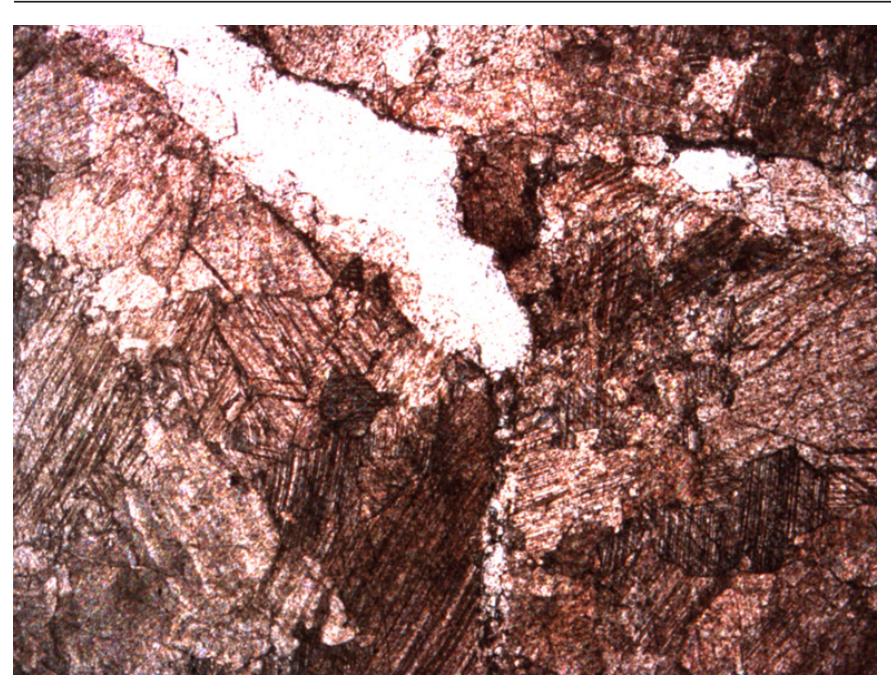

Fig. 9. Irregular pores in a thin-section of dolostone from the Sierra de las Nieves karst aquifer (Málaga, Spain). The width of the section is $2 \mathrm{~cm}$.

as a power law. They analysed the mapped karst network as spatially embedded graphs and computed the fractal dimensions by using the scale-invariant re-normalisation procedure proposed by Song et al. (2005) for complex networks.

\section{DISCUSSION}

Many features of karst terrains exhibit fractal behaviour and several theoretical models have been proposed to explain why this should be so. Mandelbrot (1983) proposes a conjecture in relation to the power law of the size-distribution of lakes that can be applied to karst geoforms. He proposes that the underlying reason that the power-law is found in nature is its "resistance" to different forms of "torture"; for example, multiplying the multiplicand in the power law by an arbitrary multiplier does not change the form of the power law. The multiplicand may be determined by an initial state in which the terrain has a power law character and the multiplier can involve many geological and tectonic factors that affect the form of the karst features. In karst terrains, the initial state of the karst system before any extensive dissolution process takes place, is fractured carbonate rocks; and fracture networks have been shown to have a fractal character (Barton, 1995; Berkowitz, 2002; Kruhl, 2013). The multiplier is a measure of the interplay of all the processes involved in the formation of karst features (Ford \& Williams, 2007), the product of which is fractal, as shown in the work presented here. This raises the obvious question of why fracture networks are fractals in the first place and a number of physical arguments have been provided and reviewed in Bonnet et al. (2001), in particular, the absence of characteristic length scales in the fracture growth process.

Multifractal analysis is a generalization of fractal analysis (Stanley \& Meakin, 1988). It can identify cases in which the fractal dimension is not constant over all scales of variability. Thus, instead of a single fractal dimension, a complete range of values, the fractal spectrum, is estimated from the experimental data (Majone et al., 2002, 2004). However, multifractal analysis requires significantly more experimental data than fractal analysis, which may explain why it has not found many applications in karst studies.

\section{CONCLUSIONS}

Fractals are widespread in nature including karst geomorphology and karst hydrogeology. Although the fractal concept does not appear in standard textbooks of karst geomorphology and hydrogeology (Ford \& Williams, 2007) and speleogenesis (Klimchouk et al., 2000), recent publications, discussed in this review, have shown that fractals in karst, far from being a mere scientific curiosity, have important practical applications that can contribute to advancing karst and cave science. There are many practical uses of the fractal analysis of karst features. For example, fractal extrapolation can be used to determine the number of small features that cannot be measured because of the fixed range of variation of the available data; fractal simulation can be used to generate realistic synthetic karst features that can be included in mathematical models (Pardo-Igúzquiza et al., 2012; Hendrick \& Renard, 2016b); fractal indices can be used as geomorphometric parameters that can be linked to physical generation processes or used to compare different karst massifs. The best of fractal analysis in karst is still to come, as modern techniques (such as LIDAR) for mapping the karst landscape and laser mapping of cave interiors will provide the required high-resolution data. Fractal analysis will then provide a means of exploring and understanding high-detail features. We conclude with the open question of why nature in general, and karst systems in particular, tend to have fractal geometry and why natural variables tend to follow a fractal distribution. Physicists have started to address this question (Sornette, 2006) although many unknowns remain.

\section{ACKNOWLEDGEMENTS}

This work was supported by research project CGL2015-71510-R of the Ministerio de Economia, Industria y Competitividad of Spain. We thank Jean Bottazi (Plongée Spéléo Club Jeunes Années, PSCJA) for providing the data for the Shuanghe cave system. We thank Jean-Pierre Cassou (Groupe de Recherches et d'Activités Spéléo, Lourdes, France) for providing the Réssau de Sakany data. We thank the speleologists of the Grupo de Exploraciones Subterráneas from the Sociedad Excursionista de Málaga for providing the data from the Sierra de las Nieves cave system. We would like to thank the detailed comments of the anonymous reviewers that have helped to improve the final version of this paper.

\section{REFERENCES}

Andreychouk V., Blachowicz T. \& Domino K., 2013 Fractal dimensions of gypsum cave-mazes of Western Ukraine. Speleology and Karstology, 11: 40-47. http://institute.speleoukraine.net/sk-issues-eng/ issue 11-eng 
Avnir D., Biham O., Lidar D. \& Malcai O., 1998 - Is the geometry of nature fractal? Science, 279: 39-40. https://doi.org/10.1126/science.279.5347.39

Bacdk S.J. \& Krothe N.C., 2001 - Derivation of effective hydraulic parameters of a karst aquifer from discharge hydrograph analysis. Water Resources Research, 37: 13-19. https://doi.org/10.1029/2000WR900247

Bakalowicz M., 2005 - Karst groundwater: a challenge for new resources. Hydrogeology Journal, 13: 148-160. https://doi.org/10.1007/s10040-004-0402-9

Barton C.C., 1995 - Fractal analysis of scaling and spatial clustering of fractures. In: Barton C.C. \& La Pointe P.R. (Eds.), Fractal in the earth sciences. Plenum Press, New York, p. 141-178. https://doi.org/10.1007/978-1-4899-1397-5_8

Belmonte-Ribas A., 2004-Aportaciones a la geomorfología del macizo de Cotiella. Lucas Mallada, 11: 25-40.

Ben-Avraham D. \& Havlin S., 2000 - Diffusion and reactions in fractals and disordered systems. Cambridge University Press, Cambridge, 332 p. https://doi.org/10.1017/CBO9780511605826

Berkowitz B., 2002 - Characterizing flow and transport in fractured geological media: A review. Advances Water Resources, 25: 861-884.

https://doi.org/10.1016/S0309-1708(02)00042-8

Bonnet E., Bour O., Odling N.E., Davy P., Main I., Cowie P. \& Berkowitz B., 2001 - Scaling of fracture systems in geological media. Reviews of Geophysics, 39: 347-383. https://doi.org/10.1029/1999RG000074

Borrough P.A., 1981 - Fractal dimensions of landscapes and other environmental data. Nature, 294: 240-243. https://doi.org/10.1038/294240a0

Bottazzi J., 2004 - Shuanghedongqun la plus longue grotte de Chine. Spelunca, 93: 13-28.

Bour O., Davy P., Darcel C. \& Odling N., 2002 A statistical scaling model for fracture network geometry, with validation on a multiscale mapping of a joint network (Hornelen Basin, Norway). Journal of Geophysical Research, 107: 1-12. https://doi.org/10.1029/2001JB000176

Cassou J.-P. \& Bigot J.-Y., 2007 - Le labyrinthe de la grotte de Sakany (Quié, Ariège). Actes de la 17\# Recontre d'Octubre, Orgnac, p. 29-36.

Crovelli R.A. \& Barton C.C., 1993 - Fractals and the Pareto distribution applied to petroleum accumulationsize distributions. U.S. Department of Interior. United States Geological Survey, Open-File Report 91-18, 29 p.

Crovelli R.A. \& Barton C.C., 1995 - Fractals and the Pareto distribution applied to petroleum accumulation-size distributions. In: Barton C.C. \& La Pointe P.R. (Eds.), Fractals in petroleum geology and earth processes. Plenum Press, New York, p. 59-72. https://doi.org/10.1007/978-1-4615-1815-0 4

Curl R.L., 1960 - Stochastic models of cavern development. Bulletin National Speleological Society, 22: 66-76.

Curl R.L., 1964 - On the definition of a cave. Bulletin National Speleological Society, 26: 1-6.

Curl R.L., 1966 - Caves as a measure of karst. Journal of Geology, 74: 798-830.

https://doi.org/10.1086/627212

Curl R.L., 1986 - Fractal Dimensions and Geometries of Caves. Mathematical Geology, 18: 765-783.

https://doi.org/10.1007/BF00899743

Dodds P.S. \& Rothman D.H., 2000 - Scaling, universality, and geomorphology. Annual Review Earth Planetary Sciences, 28: 571-610.

https://doi.org/10.1146/annurev.earth.28.1.571

Falconer K.J., 1990 - Fractal geometry: Mathematical foundations and applications. John Wiley \& Sons, Chichester (UK), 368 p.
Ford D.C. \& Ewers R.O., 1978 - The development of limestone cave systems in the dimensions of length and depth. International Journal of Speleology, 10: 213-244. https://doi.org/10.5038/1827-806X.10.3.1

Ford D.C. \& Williams P., 2007 - Karst hydrogeology and geomorphology. John Wiley \& Sons, Chichester, 562 p. https://doi.org/10.1002/9781118684986

Ghanbarian B. \& Hunt A.G. (Eds), 2017 - Fractals: concepts and applications in geosciences. CRC Press, Boca Ratón, 352 p. https://doi.org/10.1201/9781315152264

Hutchinson J.E., 1991 - Fractals and self-similarity. Indiana University Mathematical Journal, 30: 713-747. https://doi.org/10.1512/iumj.1981.30.30055

Havlin S. \& Ben-Avraham D., 1982 - Theoretical and numerical study of fractal dimensionality in selfavoiding walks. Physical Review A, 26: 1728-1734. https://doi.org/10.1103/PhysRevA.26.1728

Hendrick M. \& Renard P., 2016a - Fractal dimension, walk dimension and conductivity exponent of karst networks around Tulum. Frontiers in Physics, 4: 27. https://doi.org/10.3389/fphy.2016.00027

Hendrick M. \& Renard P., 2016b - Subnetworks of percolation backbones to model karst systems around Tulum, Mexico. Frontiers in Physics, 4: 43. https://doi.org/10.3389/fphy.2016.00043

Hergarten S. \& Birk S., 2007 - A fractal approach to the recession of spring hydrographs. Geophysical Research Letters, 34 (11): L11401. https://doi.org/10.1029/2007GL030097

Huchra J.P., Macri L.M., Masters K.L., Jarrett T.H., Berlind P., Calkins M., Crook A.C., Cutri R., Erdoğdu P., Falco E., George T., Hutcheson C.M., Lahav O., Mader J., Mink J.D., Martimbeau N., Schneider S., Skrutskie M., Tokarz S. \& Westover M., 2012 - The 2MASS redshift survey - Description and data release. The Astrophysical Journal Supplement Series, 199 (6): 1-22. https://doi.org/10.1088/0067-0049/199/2/26

Imre A.R. \& Novotný J., 2016 - Fractals and the Korcaklaw: a history and a correction. The European Physical Journal H, 41: 69-91. https://doi.org/10.1140/epjh/e2016-60039-8

Jang J. \& Jang Y.H., 2012 - Spatial distributions of islands in fractal surfaces and natural surfaces. Chaos, Solitons \& Fractals, 45: 1453-1459.

https://doi.org/10.1016/j.chaos.2012.09.003

Jeannin P.-Y., Groves C. \& Häuselaman P., 2007 Speleological investigations. In: N. Goldscheider \& D. Drew (Eds.), Methods in karst hydrogeology. Taylor \& Francis, London, p. 25-44.

Katz A.J. \& Thompson A.H., 1985 - Fractal Sandstone Pores: Implications for Conductivity and Pore Formation. Physical Review Letters, 54: 1325.

https://doi.org/10.1103/PhysRevLett.54.1325

Kaufmann G. \& Braun J., 2000 - Karst aquifer evolution in fractured, porous rocks. Water Resources Research, 36: 1381-1391. https://doi.org/10.1029/1999WR900356

Klimchouk A.B., Ford D.C., Palmer A.N. \& Dreybrodt W. (Eds.), 2000 - Speleogenesis. Evolution of karst aquifers, National Speleological Society, Huntsville, 527 p.

Klinkenberg B. \& Goodchild M.F., 1992 - The fractal properties of topography: a comparison of methods. Earth Surface Processes and Landforms, 17: 217-234. https://doi.org/10.1002/esp.3290170303

Korvin G., 1992 - Fractal models in earth sciences. WH. Freeman, San Francisco, 424 p.

Kruhl J.H., 2013 - Fractal-geometry techniques in the quantification of complex rock structures: A special view on scaling regimes, inhomogeneity and anisotropy. Journal of Structural Geology, 46: 2-21. https://doi.org/10.1016/j.jsg.2012.10.002 
Kusumayudha S.B. \& Zen M.T., Notosiswoyo S. \& Gautama R.S., 2000 - Fractal analysis of the Oyo River, cave systems, and topography of the Gunungsewu karst area, central Java, Indonesia. Hydrogeology Journal, 8: 271-278. https://doi.org/10.1007/s100400050014

Lauber U., Ufrecht W. \& Goldscheider N., 2014. Spatially resolved information on karst conduit flow from in-cave dye tracing. Hydrology and Earth System Sciences, 18: 435-445. https://doi.org/10.5194/hess-18-435-2014

Laverty M., 1987 - Fractals in karst. Earth Surface Processes and Landforms, 12: 475-480.

https://doi.org/10.1002/esp.3290120505

Lenormand R., 1997 - Fractals and porous media. From pore to geological scales. In: Carpinteri A. \& Mainardi F. (Eds.), Fractals and fractional calculus in continuum mechanics. International Centre for Mechanical Sciences (Courses and Lectures), Springer-Verlag, Vienna, p. 173-222. https://www.springer.com/us/book/9783211829134

Liucci L. \& Melelli L., 2017 - The fractal properties of topography as controlled by the interactions of tectonic, lithological and geomorphological processes. Earth Surface Processes and Landforms, 42: 2585-2598. https://doi.org/10.1002/esp.4206

López-Chicano M., 1995 - El paisaje kárstico de Sierra Gorda. Formas y evolución geodinámica reciente. Espeleotemas, 5: 31-50.

Mace R., Marrett R.A. \& Hovorka S.D., 2005 - Fractal scaling of secondary porosity in karstic exposures of the Edwards Aquifer. In: Beck B.F. (Ed.), Sinkholes and the engineering and environmental impacts of karst. American Society Civil Engineers, Geotechnical Special Publication, No. 144, 10 p. https://doi.org/10.1061/40796(177)19

Mandelbrot B.B., 1967 - How long is the coast of Britain? Statistical self-similarity and fractional dimension. Science, 156: 636-638.

https://doi.org/10.1126/science.156.3775.636

Mandelbrot B.B., 1975 - Stochastic models for the Earth's relief, shape and fractal dimension of coastlines, and number-area rule for islands. Proceedings National Academy of Sciences USA, 72: 3825-3838. https://doi.org/10.1073/pnas.72.10.3825

Mandelbrot BB., 1983 - The fractal geometry of nature. WH. Freeman, San Francisco, 460 p.

Maramathas A.J. \& Boudouvis A.G., 2006. Manifestation and measurement of the fractal characteristics of karst hydrogeological formations. Advances in Water Resources, 29: 112-116.

https://doi.org/10.1016/j.advwatres.2005.06.003

Maire R., Jaillet S. \& Hobléa F., 2003 - Karren in Patagonia, a natural laboratory for hydroaeolian dissolution. In: Ginés A., Knez M., Slabe T. \& Dreybrodt W. (Eds.), Karst rock features - Karren sculpturing. Carsologica, Publication no. 9, Postojna-Ljubljana, p. 329-348.

Majone B., Bellin A. \& Borsato A., 2002 - Fractal and multifractal analysis of the hydraulic property variations of karst aquifers. Proceedings of Calibration and Reliability in Groundwater Modelling: A Few Steps Closer to Reality ModelCARE 2002, Prague, Czech Republic, IAHS Publications 277, 148-154.

Majone B., Bellin A. \& Borsato A., 2004 - Runoff generation in karst catchments: multifractal analysis. Journal of Hydrology, 294: 176-195.

https://doi.org/10.1016/j.jhydrol.2003.11.042

Nikora V.I. \& Sapozhnikov V.B., 1993 - River network fractal geometry and its computer simulation. Water Resources Research, 29: 3569-3575.

https://doi.org/10.1029/93WR00966
Pardo-Igúzquiza E., Durán-Valsero J.J. \& RodríguezGaliano V., 2011 - Morphometric analysis of threedimensional networks of karst conduits. Geomorphology, 132: 17-28.

https://doi.org/10.1016/j.geomorph.2011.04.030

Pardo-Igúzquiza E., Dowd P.A., Xu C. \& Durán-Valsero J.J., 2012 - Stochastic simulation of karst conduit networks. Advances in Water Resources, 35: 141-150. https://doi.org/10.1016/j.advwatres.2011.09.014

Pardo-Igúzquiza E., Durán J.J. \& Dowd P.A., 2013 Automatic detection and delineation of karst terrain depressions and its application in geomorphological mapping and morphometric analysis. Acta Carsologica, 42 (1): 17-24.

https://doi.org/10.3986/ac.v42i1.637

Pardo-Igúzquiza E., Durán J.J., Robledo P., Guardiola C., Luque J.A. \& Martos S., 2014a - Fractal modelling of karst conduits. In: Pardo-Igúzquiza E. GuardiolaAlbert C., Heredia J., Moreno-Merino L., Durán J.J. \& Vargas-Guzmán J.A. (Eds.), Mathematics of Planet Earth. Springer, Berlin, p. 217-220.

Pardo-Igúzquiza E., Durán J.J., Luque-Espinar J.A. \& Martos-Rosillo S., 2014b - Análisis del relieve kárstico mediante el modelo digital de elevaciones. Aplicaciones a la Sierra de las Nieves (provincia de Málaga). Boletín Geológico y Minero, 125: 381-389.

Pardo-Igúzquiza E., Durán J.J. \& Robledo-Ardila P.A., 2016a - Modelado fractal de la distribución del tamaño de dolinas en el macizo kárstico de la Sierra de las Nieves (Málaga, España). Cuaternario y Geomorfología, 30: 61-73.

Pardo-Igúzquiza E., Durán J.J., Robledo-Ardila P., Luque-Espinar J.A., Martos-Rosillo S., GuardiolaAlbert C. \& Pedrera A., 2016b - The karst network system of the Sierra de las Nieves (Málaga, Spain). An example of a high relief Mediterranean karst. Boletin Geológico y Minero, 127: 193-204.

Pardo-Igúzquiza E., Pulido-Bosch A., López-Chicano M. \& Durán J.J., 2016c - Morphometric analysis of karst depressions on a Mediterranean karst massif. Geografiska Annaler: Series A, Physical Geography, 98: 247-263.

https://doi.org/10.1111/geoa.12135

Pardo-Igúzquiza E., Durán J.J., Balart D., Borrás E.J., Ferreres J., Quiroga E., Guillén J., Garza X., Marqués F., Robador A., Cabrera A. \& Robledo-Ardila P., 2016d - Morfometría y control geológico de las depresiones kársticas de la Sierra de Tendeñera. Geo-Temas, 16: 303-306.

Pardo-Igúzquiza E. \& Dowd P.A., 2018. Fractal analysis of karst landscapes. Submitted for publication.

Persson B.N.J., 2014 - On the fractal dimension of rough surfaces. Tribology Letters, 54: 99-106. https://doi.org/10.1007/s11249-014-0313-4

Reams M.W., 1992 - Fractal dimensions of sinkholes. Geomorphology, 5: 159-165. https://doi.org/10.1016/0169-555X(92)90063-T

Rodriguez-Iturbe I. \& Rinaldo A., 2001 - Fractal river basins: chance and self- organization. Cambridge University Press, Cambridge, 549 p.

Sapoval B., 2001- Universalités et fractals. Flammarion, Paris, $276 \mathrm{p}$.

Schroeder M., 1991 - Fractal, chaos, power laws. Minutes from an infinite paradise. W.H. Freeman and Company, New York, 429 p.

Shevenell L., 1996. Analysis of well hydrographs in a karst spring: estimates of specific yields and continuum transmissivities. Journal of Hydrology, 174: 331-355. https://doi.org/10.1016/0022-1694(95)02761-0 
Song C., Havlin S. \& Makse H.A., 2005 - Self-similarity of complex networks. Nature, 433: 392-395. https://doi.org/10.1038/nature03248

Sornette D., 2006 - Critical phenomena in natural sciences. Chaos, fractals, self-organization and disorder: Concepts and tools. Springer Series in Synergetics, Berlin, 556 p.

Stanley H.E. \& Meakin P., 1988 - Multifractality phenomena in physics and chemistry. Nature, 335: 405-409. https://doi.org/10.1038/335405a0

Stoyan D. \& Stoyan H.., 1994 - Fractals, random shapes and point fields. John Wiley \& Sons, Chichester, 389 p.

Taud H. \& Parrot J.-F., 2005 - Measurement of $D E M$ roughness using the local fractal dimension. Géomorphologie: relief, processus, environment, 11: 327-338.

Tarboton D.G., Bras R.L. \& Rodríguez-Iturbe I., 1988 The fractal nature of river networks. Water Resources Research, 24: 1317-1322. https://doi.org/10.1029/WR024i008p01317

Telbisz T., Dragušica H. \& Nagy b., 2009 - Doline morphometric analysis and karst morphology of Biokovo Mt (Croatia) based on field observations and digital terrain analysis. Croatian Geographical Bulletin, 71: 2-22. https://doi.org/10.21861/HGG.2009.71.02.01

Turcotte D.L., 1997 - Fractals and chaos in geology and geophysics. Cambridge University Press, Cambridge, 398 p. https://doi.org/10.1017/CBO9781139174695
Turcotte D.L., 2007 - Self-organized complexity in geomorphology: observations and models. Geomorphology, 91: 302-310.

https://doi.org/10.1016/j.geomorph.2007.04.016

Verbovšek T., 2007 - Fractal analysis of the distribution of cave lengths in Slovenia. Acta Carsologica, 36: 369377. https://doi.org/10.3986/ac.v36i3.170

White W.B. \& White E.L., 2003 - Conduit fragmentation, cave patterns, and the localization of karst ground water basins: the Appalachians as a test case. Speleogenesis and Evolution of Karst Aquifers, 1: 1-15.

Worhington S.R.H. \& Ford D.C., 2009 - Self-organized permeability in carbonate aquifers. Ground Water, 47: 326-336.

https://doi.org/10.1111/j.1745-6584.2009.00551.x

Xu T., Moore I.D. \& Gallant J.C., 1993 - Fractals, fractal dimensions and landscapes - a review. Geomorphology, 8: 245-262. https://doi.org/10.1016/0169-555X(93)90022-T

Yizhaq H., Ish-Shalom C., Raz E. \& Ashkenazy Y., 2017 - Scale-free distribution of Dead Sea sinkholes: Observations and modeling. Geophysical Research Letters, 44: 4944-4952. https://doi.org/10.1002/2017GL073655

Yu B. \& Liu W., 2004 - Fractal Analysis of Permeabilities for Porous Media. American Institute of Chemical Engineers Journal, 50: 46-57. https://doi.org/10.1002/aic.10004 